https://doi.org/10.52449/1857-4114.2021.37-1.03

CZU: 78.071.1:37.036

\title{
THE THEORETICAL-PRAXIOLOGICAL WARM-UP MODEL (PPAT) FOR ENTERTAINER SINGERS
}

\author{
Blîndu Adela , ORCID: 0000-0002-4932-6525 \\ ${ }^{1}$ Academy of Music, Theater and Fine Arts, Chisinau, Republic of Moldova
}

\begin{abstract}
The following article presents physical exercises and the theoretical-praxiological model for singers' warm-up. The purpose of this paper is to streamline the warm-up for entertainer singers by using PPAT means. The development of technical and interpretive skills, implementation of PPAT relevant to the field and their improvement throughout the activity are some of the most important concerns of each entertainer singer. The complex method of physical and vocal training includes body gymnastics exercises, exercises of the muscular systems that participate in the emission of sound and vocal exercises. Complex exercises are recommended for maintaining mental and physical qualities, improving general motor skills and phono-articulatory movements. These are basic not just for the development of sound emission, but also for the prevention of the so-called professional diseases. The creative development of PPAT for future specialists has a benefic effect on intellectual, emotional-volitional and practical activity. The means, methods and forms of PAPT are aimed at optimally meeting the requirements of the educational, professional, social and daily life spheres of vocalists. PPAT, as a training factor for singers, includes the following: the greater the motor experience and perceptions of the vocalist are, the more perfect the coordination of movements determines a good physical training, the faster the new action is developed, because man can previously create a preliminary model of any motor act in his mind and reproduce it quickly. The essence of PPAT is the optimal use of resources, methods and forms of physical training, in order to achieve and maintain mental and physical qualities. The artistic activity of a vocalist has possibilities to integrate the influence on his spiritual growth and, in particular, on the improvement of his personality. It is important that the specialist in the field acts with interest, with a sufficient degree of independence, in other words creative, and the creative approach to actions is the basis of education.
\end{abstract}

Keywords: PPAT (physical professional applied training), artist - vocalist, vocal apparatus, artistic activity, motor experience, respiration types, theoretical-praxiological mode.

Introduction. Artistic activity involves the possibilities of integrating and improving the personality. Nowadays, innovative methods of training professional skills and creative capacities are increasingly emerging the contemporary society, offering future vocalists the possibility of self-learning and self-education. For example, researchers [1, 2, $4,5,6]$ have developed a set of vocal and physical exercises for preparing the vocal apparatus for the activity. Compared to the vocal capabilities, the functional premise is manifested through movements (gestures, mimics, basic position, stage moves, etc.) that are formed during the study process of young vocalists.

Basic content.

Some authors consider as the vocal apparatus only the larynx which is a complex organ that functions as a sphincter at the junction between the digestive tract and the respiratory tract and participates in the 
protection of the respiratory tract, respiration and phonation. False vocal cords (vestibular ligaments), true vocal cords (vocal ligaments), epiglottis, thyroid cartilage and cricoid cartilage are located in the larynx. Others [3, $6,8]$ include in the same notion, in addition to the larynx, the respiratory apparatus - the "respiratory system" with the entire system of bones and muscles, including the diaphragm, which is the main muscle of respiration, going to the abdominal region and pelvis. The human respiratory system consists of two categories of organs: the airways (nasal cavity, pharynx, larynx, trachea, bronchi) and respiratory organs - the lungs that play the most important role in respiration; pulmonary respiration takes place at this level; gas exchange between organism and environment occurring in the alveoli of the lungs [7]. The oral cavity of the respiratory system ensures the direct passage of air from the outside to the lungs and vice versa, at this level the air is subjected to processes of wetting and warm-up. The oral cavity has several functions. One of them is the relationship function through which the body integrates into the living environment. The major importance of this function is the transformation of the sounds emitted by the vocal cords into words through the soft palate, tongue and lips, the oral cavity giving resonance to the voice. In the oral cavity are located lips, teeth, tongue, hard palate, uvula. At the beginning of life, the respiratory system has only one vital function: the gas exchanges necessary for the maintenance of life. During the first period of childhood, the same device gains a new function - speech. Of course, the old function is preserved. Through an adequate education, the same apparatus specializes for singing, gaining another function - the vocal function, hence the name of the vocal apparatus (Figure 1).

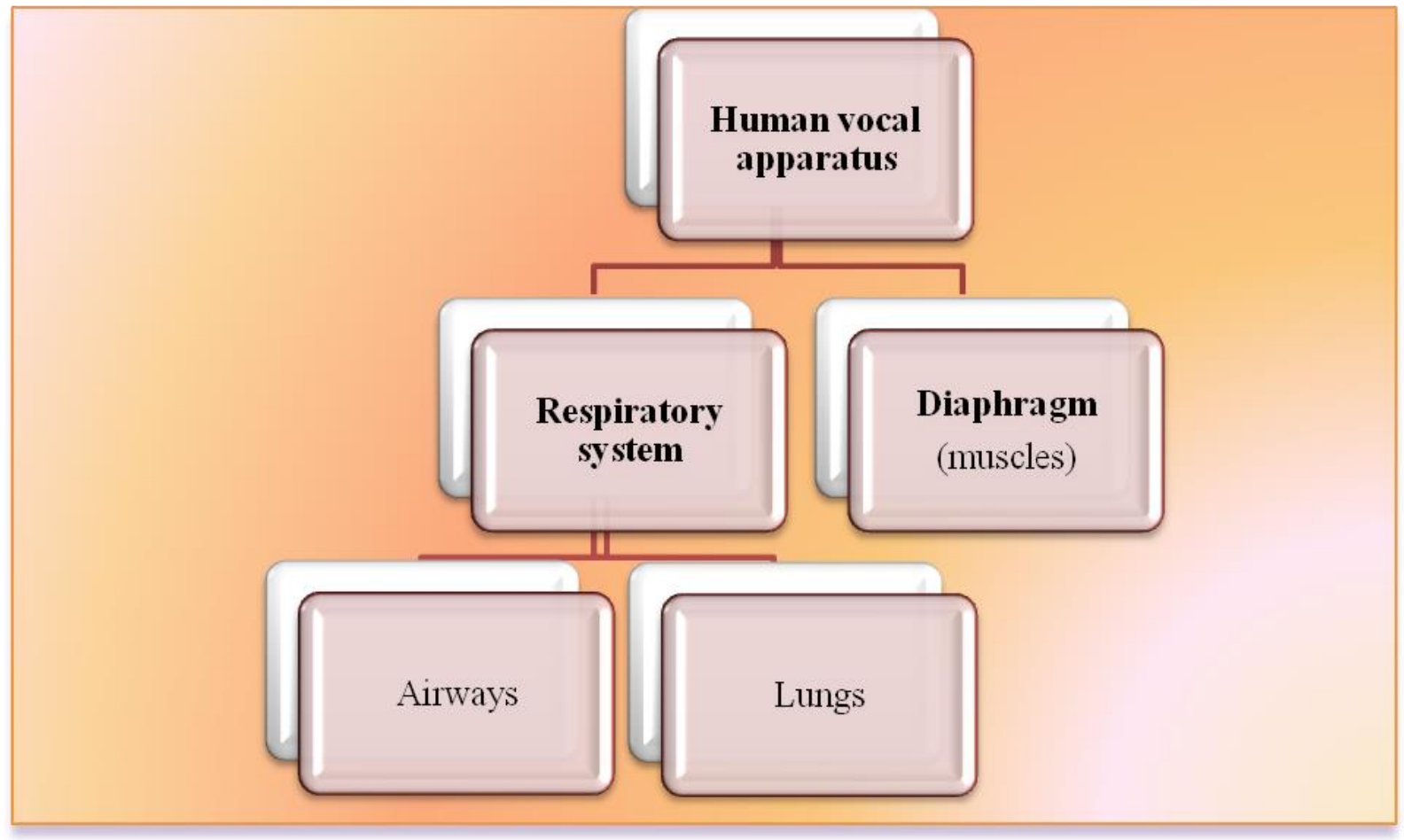

Fig.1. Human vocal apparatus

The diaphragm, after the heart, is the most important muscle in the human body and has the role of maintaining proper breathing and, implicitly, health and physical, mental and 
emotional balance. Marin-Marius Truiculescu in the book Professional vocal singing mentions: "the diaphragm is a muscle-membrane septum, arched like a dome toward thorax through two unequal domes, the dome on the left being smaller and lower due of the heart which has its place a little to the left (between the two domes there is a place called "the bed of the heart")" [4 p.69]. The vocal apparatus is composed of various muscle groups, which, through their movements and contraction, help us to articulate and emit sound correctly. Muscle groups can be divided into: a) body' muscles, which provide air supply to the vocal cords and, at the same time, contribute to the correct position of the larynx; b) the laryngeal muscles, which are directly involved in the production of vibrations, as well as the muscles of neck, which are attached to the larynx and coordinate its activity; c) the muscles of the phono-articulating apparatus, which function consists of transforming the sound emitted into clear speech. Exercises aimed at strengthening the muscles of the phono-articulatory apparatus are used to develop facial expression (Figure 2) and myogymnastics exercises are divided into three categories, namely: lip gymnastics, mandible gymnastics, tongue gymnastics.

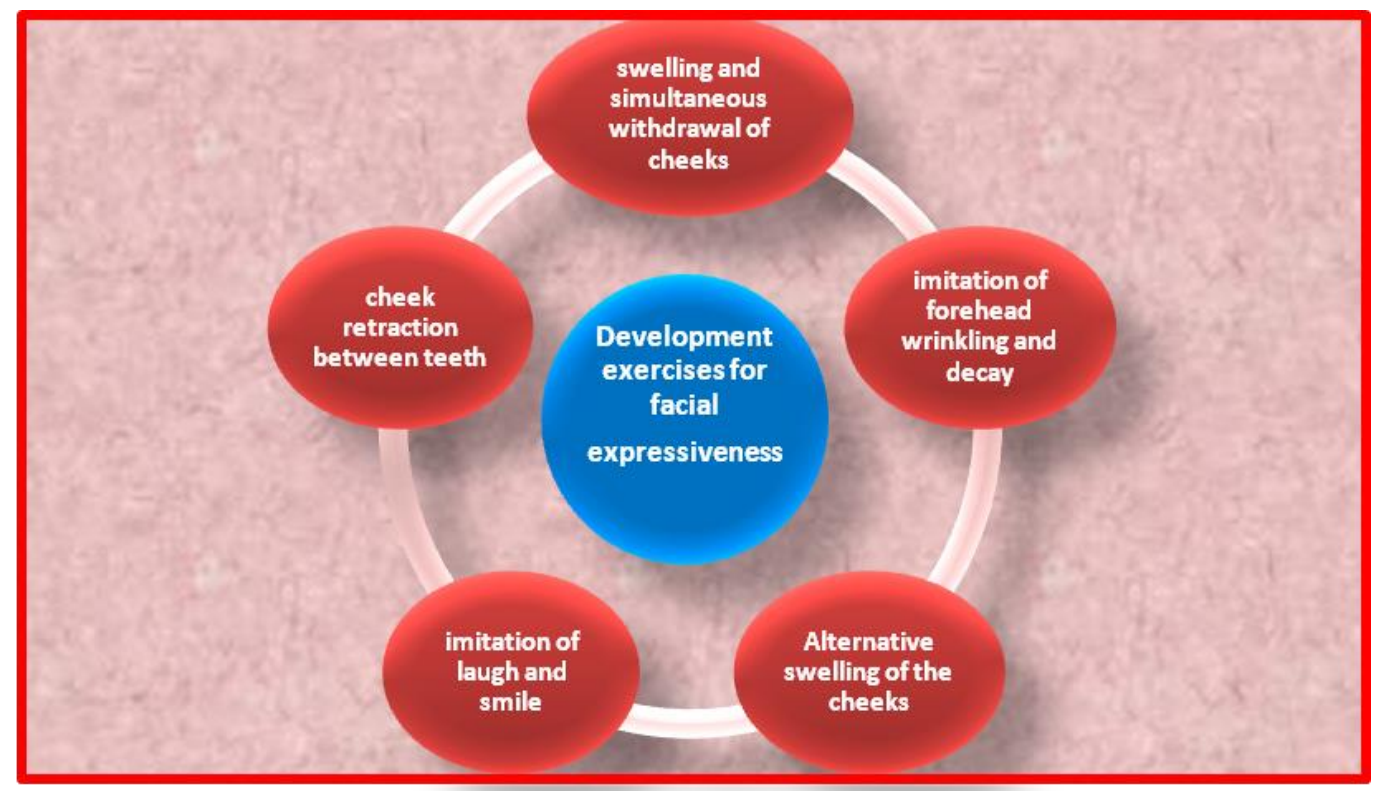

Fig.2. Development exercises for facial expressiveness

Examples of myogymnastics:

Lip gymnastics:

1. The motor (lips vibrate) scared)

2. Imitating different emotions (sad, happy,

3. Emit vowels (a, e, i, o, u)

4. Upper lip over lower lip

Tongue gymnastics:

1. Move mandible forward / backward / left / right

2. Imitation of yawning

3. Rhythmic raising and lowering the mandible.
Lingual gymnastics:

1. Rhythmic movements of forwarding/ backwarding the mandible,

2. Right-left movements

3. Get out the tongue in the form of a shovel

4. Get out the tongue in the form of an arrow.

Purpose and methods. For entertainer singers, PPAT is aimed at preventing muscle stiffness and contributes to better flexibility and agility in sound emission. Exercises can be indicated to improve general motor skills, which are of particular importance not only for the 
development of sound emission, but also for the health of the body. Any movement will be performed rhythmically, which will facilitate the introduction of rhythm in speech and these exercises will always be associated with breathing.

There are two categories of exercises:

a) which aim to relax the body and muscles of the emission apparatus;

b) which aim to tension, being used especially during the pronunciation of deaf sounds.

These exercises are intended to prepare the singer for maintaining the position and physical condition necessary for singing. Examples of exercises: rotating the shoulders in both directions (back, front)/shaking hands and arms/rotating the torso/lowering the head forward/ lowering the head to the right then to the left, each time returning to the initial position.

In classical singing, correct breathing is essential because the musical phrases are long and the pauses for breathing are to the detriment of the vocalist. In the stage singing, the vocalist makes his own rules and can often take a few breaths, but it is very good to breathe correctly for a well-supported phrase. Women breathe differently than men: men have diaphragmatic breathing, women - thoracic breathing. Why do we breathe differently and "wrong"?

Because, physiologically, woman is made to procreate and uses chest breathing so as not to affect the fetus. In diaphragmatic breathing, the diaphragm moves down and presses on the abdominal area. In thoracic breathing, the diaphragm does not move and thus does not disturb the fetus during pregnancy. According to the degree of involvement of the muscles in the respiratory act, the types of respiration are determined as being: thoracic, intercostal, abdominal, nasal, intercost - diaphragmatic or total - the most used by vocalists (Figure 3).

The costal-diaphragmatic breathing is most often used by professional vocalists. Octav Cristescu, in the book Singing, problems of technique and vocal interpretation, mentions the following: „Physiologically, the costaldiaphragmatic breathing is easy, having a large inspiratory cavity in which a rich amount of air can be stored, given that the region where this process takes place is very elastic" [3, p.69].

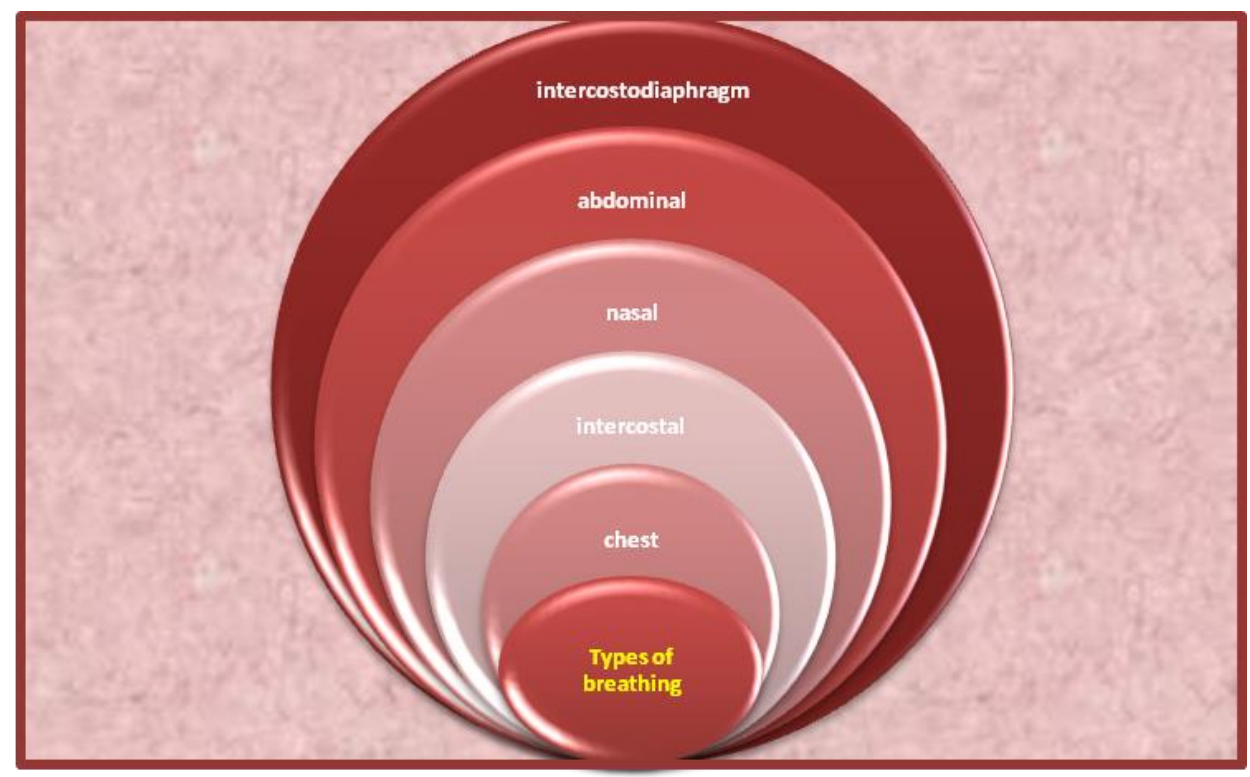

Fig.3. Types of breath

Examples of total breathing awareness exercises:
- lie on your back and breathe thinking about sending air to the intercostal, abdominal or 
lung area. Naturally, the back should touch the floor;

- looking in the mirror, try not to inflate the chest during inspiration, not to raise the shoulders and try to channel all the inspired air in the abdominal or costal area of the lungs, etc.

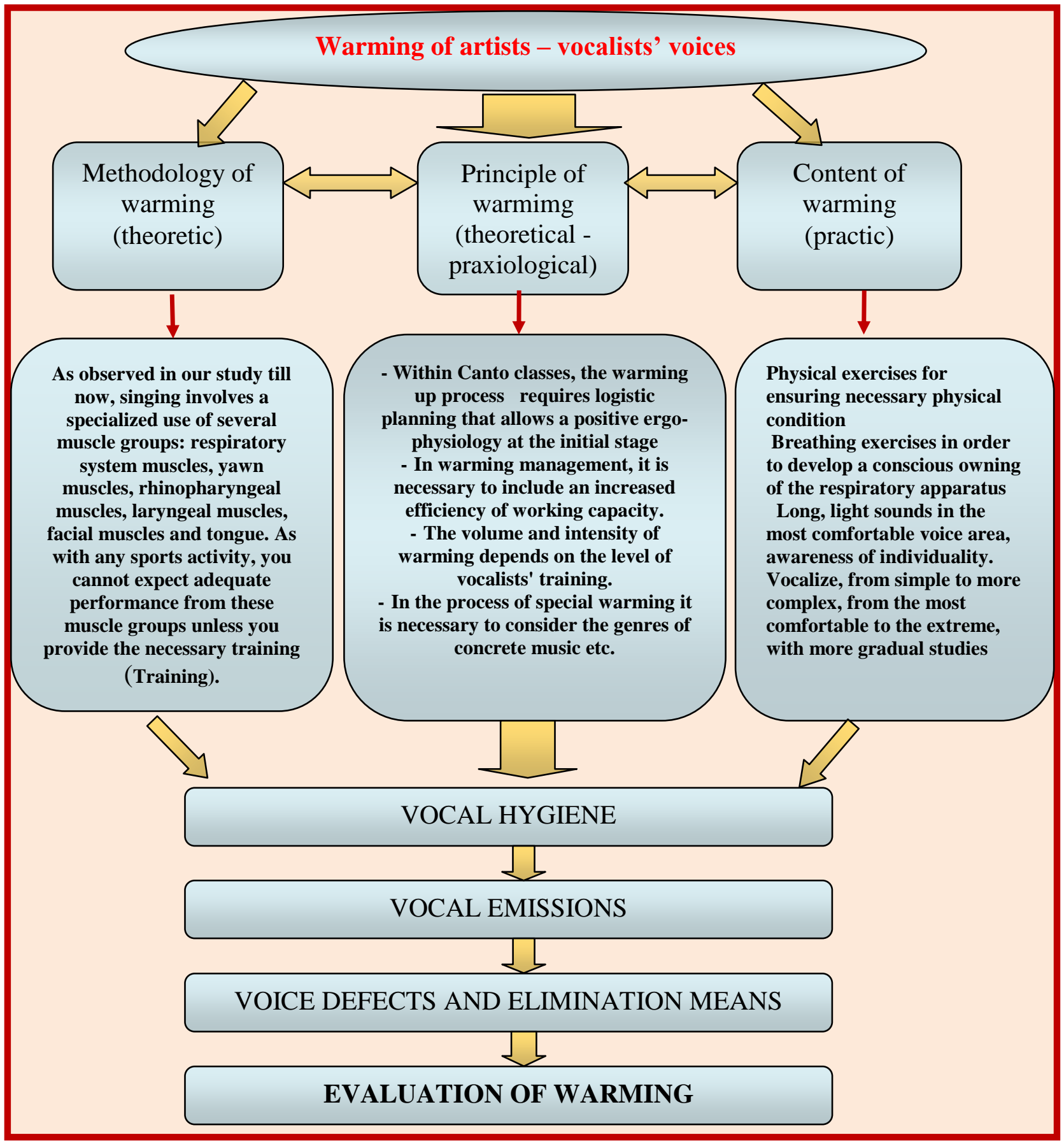

Fig. 4. Theoretical-praxiological model for warming up the artists-vocalists'voices

Expiration exercises: blow your nose in the handkerchief/blow the air on the back of your hand/blow a candle/ inflate a balloon, etc. Differentiated inspiration exercises: 
facing the mirror take 3 inspirations and 5 expirations; mouth inspiration and nasal expiration; nose inspiration and mouth expiration, etc. Exercises for pronouncing groups of vowels during an expiration (ai, ei, oi, ua, ue etc.). As we observed in our study, singing involves a specialized use of several muscle groups: the muscles of the respiratory system, the muscles of the nasopharyngeal area, the laryngeal muscles, the facial muscles and the tongue. As in any sports activity, you cannot expect adequate performance from these muscle groups if you do not provide them with the necessary training.

Analysis of the results. Special physical exercises help singers to emit sound correctly, to develop breathing and to increase work capacity [6]. Some exercises will be performed before the vocal training, others will be performed daily, regardless of the vocal training. Based on desk analysis, as well as according to the opinion of artists-vocalists (the results of the surveys will be communicated later after the statisticalmathematical processing of the obtained data), we elaborated a theoreticalpraxiological model on the use of professional-applied physical training for the professional activity of singers. In order to improve the general motor skills and the correct sound emission, we developed and algorithmized the methodology of warm-up for singers by means of professional-applied physical training. Based on the specialized literature and IT materials, we selected the theoretical-praxiological principles for the training of the vocal apparatus. We elaborated the practical content of means for professional physical training, as well as the integrated theoretical-praxiological warm-up model for singers (Figure 4).

\section{References:}

1. Budoiu I. (1979). Metodica predării cântului. Cluj-Napoca, p. 32-50.

2. Bullui A. (1989). Introducere în arta cântului. Bucureşti, p. 6-33.

3. Cristescu O. (1963). Cântul, probleme de tehnică și interpretare vocală. București: Editura muzicală a Uniunii Compozitorilor din RPR, p. 69.

4. Truiculescu M-M. (2011). Cântul vocal profesionist. Cluj-Napoca: Editura Renașterea, p. 69. ISBN 978-973-1714- 99-8.

5. Алферова Т.В., Яременко В.В., Казанцева С.И., Руденко Л.В. (1983). Влияние специальной гимнастики на функиию внешнего дыхания // Теория и практика физической культуры, №8, с.27-28.

6. Аникеева 3., Аникеев Ф. (1981). Как развить певческий голос. Кишинев: «Штиинца», c. 45-55.

\section{Electronic sources:}

7. Anatomia omului. http://www.anatomie.romedic.ro/ (accesat la 20.05.2020)

8. Măru E. Anatomia și fiziologia umană a aparatului respirator și fonator, p. 5 https://www.unatc.ro/doctorat/sustinere/Anunt_rezumat_maru_elena.pdf (accesat la 20.05.2020) 